\title{
The Factors of Fraud Trends in Public Sector in Makassar City
}

\author{
Arman Kamal ${ }^{1}$, Diah Ayu Gustiningsih ${ }^{2}$, Mediaty ${ }^{3}$, Abdul Hamid Habbe ${ }^{4}$ and Arifuddin ${ }^{5}$ \\ ${ }^{1}$ STIE Tri Dharma Nusantara, Indonesia \\ ${ }^{2}$ STIE Tri Dharma Nusantara, Indonesia \\ ${ }^{3}$ Hasanuddin University, Indonesia \\ ${ }^{4}$ Hasanuddin University, Indonesia \\ ${ }^{5}$ Hasanuddin University, Indonesia
}

\begin{abstract}
This study aims to obtain empirical evidence about the factors causing fraud trends in public sector organizations in the city of Makassar. The variables tested were distributive justice, procedural fairness, internal control system, leadership style, and organizational ethical culture. The sample used in this research is 83 samples working in the public sector in Makassar city. The sample is selected from several public sector agencies with a convenience sample technique. Hypothesis testing using SEM (Structural equations model) analysis tool using Smart PLS application. 03 to test the indicators that make up the construct and test the influence of variables that influence foul tendencies. The result of the research shows the influence of procedural justice, internal control system and leadership style to the tendency of fraud.
\end{abstract}

Keywords: Fraud, Public sector

\section{Introduction}

Generally, accounting cheating is related to corruption. Corruption is a fraudulent case often found in the government sector. Actions that are commonly done include manipulating the recording, removal of documents and mark-ups that harm the country's economy. In addition, according to the Association of Certified Fraud Examiners (ACFE) in addition to corruption, two other types of fraud are a fraud against assets and fraud to the financial statements. Indonesia Corruption Watch (ICW) reveals corruption data in 2017. There are 576 cases of corruption with 1,298 suspects causing state losses of Rp. 6.5 Trillion with Rp. 211 Billion from bribery cases. The following corruption data from the five most corrupt sectors by 2017.

Table 1. Corruption of the five most corrupt sectors

\begin{tabular}{|l|l|c|c|}
\hline No. & \multicolumn{1}{|c|}{ The most corrupt sector } & Number of Cases & State Losses (Billion) \\
\hline 1 & Village Budget & 98 Cases & Rp. 39,3 \\
\hline 2 & Government & 55 Cases & Rp. 255 \\
\hline 3 & Education & 53 Cases & Rp. 81,8 \\
\hline 4 & Transportation & 52 Cases & Rp. 985 \\
\hline 5 & Societies & 40 Cases & Rp. 41,1 \\
\hline
\end{tabular}

Based on these data, corruption cases are increasing with the most common mode of corruption used by offenders is budget misuse. While the second mode by way of markup and illegal fees as well as bribery and gratification. However, when viewed from the side of the budget, the village budget is the most corrupt sector, then the government sector and education. Based on the data, the province with the most cases of corruption in East Java with a state loss of Rp. 90.2 Billion. In addition, corruption also often occurs when the authorities receive money to speed up services or collect money on services that should be free and do not require a fee. This phenomenon often occurs in various government services in Indonesia. This is certainly very detrimental to other people who use government services. On the one hand, speed up and give priority to service but on the other side, of course, disadvantage user service that has been queuing up first. (Setiawan, 2016). 
Fraud Triangle is a model that explains the reason people do fraud including corruption. This fraudulent triangle concept was first introduced by Cressey (1953) in his dissertation. Cressey is interested in embezzlers who he calls "trust violators" or breakers of trust, those who violate trust or trust entrusted to them. The Fraud Triangle Theory developed by Cressey (1953), says that cheating is caused by three factors, consisting of pressure (Pressure), Opportunity, and Rationalization.

Research conducted by Allen and Hamilton (1999) found results that Indonesia has the lowest index of good governance and the highest level of corruption compared with some countries in Southeast Asia. Furthermore, Wilopo (2006) examines the causes of accounting fraud by using variables such as internal control, compensation, adherence to accounting rules, information asymmetry, management morality, to unethical behavior and fraudulent accounting trends. Betts (2009) examines the various reasons employee fraud by looking at variables from the psychological and demographic side in America. Based on the educational background and age of the respondents, the study found that accounting fraud in the United States was dominated by S1 graduates and based on the number of corruptions dominated by graduates of S2 and the age of employees who accounted for the most fraud accounting age is $40-50$ years.

Related to the factors that influence fraud in the government sector, some research has been done before. Among them is research conducted Pramudita (2013) which examines the analysis of fraud in the government sector of Salatiga City. The variables used are fraud in the government sector, leadership style, the effectiveness of the internal control system, organizational commitment, compensation suitability, organizational ethical culture, law enforcement. The results of this study indicate that there is a negative influence between the effectiveness of internal control system, compensation suitability, organizational ethical culture, leadership style to fraud in the government sector and there is no influence between organizational commitment and law enforcement on fraud in the government sector.

This study was conducted by exploring the perception of the respondents. The variables to be tested influence on the tendency of accounting fraud namely distributive justice, procedural fairness, internal control system, leadership style, and organizational ethical culture.

Theory and Hypotheses. The attributional theory according to Robbins \& Stephen (2003) is the way men judge people differently, depending on what meanings are linked to a behavior. Basically, this theory suggests that if one observes an individual's individual behavior, the person seeks to determine whether the behavior is due to internal or external factors.

Attribution theory explains how one understands the events around them, knowing the reasons for the events they are experiencing. Dispositional attributions or internal causes refer to aspects of individual behavior that exist in a person such as nature, self-perception, ability, motivation. While situational attributions or external causes that refer to the surrounding environment that can affect behavior, such as social conditions, social values, and views of society. In other words, any action or idea that someone will do will be influenced by internal and external factors.

This study uses the Fraud Triangle Theory as the main theoretical basis. In the fraud triangle theory, there is a fraudulent triangle model that is created to answer the question, why people cheat, or why cheating occurs. Cressey concludes that: A person who is believed to be a believer when he sees himself as a person who has financial problems that cannot be told to others, aware that this problem can secretly overcome by abuse of his authority as a holder of trust in the field of finance, and allows adjusting views about himself as someone who can be trusted in using funds or wealth entrusted. Cressey in Tuanakotta (2010) concludes that cheating generally has three traits in this theory: "Opportunity, Pressure, and Rationalization."

According to Gbegi and Adebisi (2015), Fraud can be interpreted as a generic term and encompasses all means with various human ingenuity designed by one individual to profit more than another with false information. The Association of Certified Fraud Examiners (ACFE) (2008) uses the term "occupational Fraud and abuse" and defines it as the use of one's position to enrich oneself through intentional abuse or misuse of resources or organizational assets. The Occupational tree has three 
main branches, namely Fraudulent Statements, Asset Misappropriation, and Corruption. Fraud is not just corruption but there are many derivatives of fraud.

Factors Causing Fraud Trends (Fraud). Conceptually distributive justice is concerned with the distribution of circumstances and goods that will affect the well-being of the individual. Welfare includes physical, psychological, economic and social aspects. The distributive justice research in organizations today focuses primarily on a person's perception of the fairness of the outcomes they receive, i.e. their assessment of the final conditions of the Palupi allocation process (2013). Distributive justice is justice relating to the distribution of resources and criteria used to determine the allocation of those resources. This kind of justice involves the problem of one's perception of the fairness of the career they receive.

At the beginning of the development of theory and research of organizational justice, more focus on distributive justice. Justice studies focus on people's feelings and behaviors in social interactions derived from judgments of fairness over the results they receive when transacting with others. The main concern of the research is in the theory of inequity (Adams, 1965 in Schminke, Ambrose \& Noel, 1997). The hypothesis of a very dominant role of distributive justice is widely supported. In a Walster experimental study, Walster and Berscheid (1978) showed that people feel most satisfied when their results are fairly distributed (Tyler \& Blader, 2003).

Rawls (2009) formulates two principles of distributive justice, as follows:

a. The greatest equal principle, that everyone should have equal rights over the broadest basic freedoms, as wide as equal freedom for all. This is the most fundamental thing (human rights) that everybody should have.

b. Social and economic inequality should be regulated in such a way that it is necessary to consider the following principles or principles: (1) the different principle, and (2) the principle of fair equality of opportunity. This principle is expected to provide the greatest benefit to the less fortunate and affirms that with the same conditions and opportunities all positions and positions must be open to all (The Principle of Objective Differences). The second principle, namely "the different principle" and "the principle of equality of opportunity", according to the author is "the principle of objective difference", meaning that the second principle ensures the proportionality of the exchange of rights and obligations of the parties, ) acceptable difference of exchange provided that the qualified good faith and fairness.

The existence of injustice causes a person to commit fraud.

H1: Distributive justice negatively affects fraud trends in the public sector.

Procedural justice is a consideration that employees make about the perceived fairness of the processes and organizational procedures used to make allocation and resource decisions (Ivancevich, 2006). According to Greenberg and Baron (2003), procedural justice is defined as the perception of justice for decision-making in organizations. People in the organization are very concerned about making decisions fairly. They feel that organizations and employees will benefit equally if the organization executes the procedure fairly. While the definition of procedural justice is the perceived fairness of the processes and procedures used to allocate decisions (Thibaut and Walker 1978). The findings of a number of studies show that justice does not simply compare inputs and outputs but can be identified how processes and procedures are in determining an outcome (Palupi, 2013). The process of unjust procedural decision-making causes employees to tend to cheat.

$\mathrm{H} 2$ : Procedural justice negatively affects fraud trends in the public sector.

Wilopo (2006), said that the internal control system for an organization is very important, namely, to provide protection for the entity against human weakness and to reduce the possibility of errors and actions that are not in accordance with the rules. The development of government internal control in Indonesia is marked by the issuance of Government Regulation (PP) No. 60 of 2008 on Government Internal Control System (SPIP). The internal control system according to PP SPIP is an integral process on actions and activities conducted continuously by the leadership and all employees to provide reasonable assurance on the achievement of organizational goals through effective and 
efficient activities, reliability of financial reporting, the security of state assets, and adherence to legislation.

The internal control system is a process run to provide reasonable assurance about achieving the reliability of financial statements, compliance with laws, and the effectiveness and efficiency of operations. Meanwhile, according to Puspasari and Suwardi (2012), accounting controls are part of the internal control system, including organizational structure, methods, and measures that are coordinated primarily to safeguard the organization's wealth and check the accuracy and reliability of accounting data.

According to the Committee of Sponsoring Organizations (COSO, 2004), internal controls are designed to provide reasonable assurance about the achievement of objectives on the effectiveness and efficiency of operations, reliability of financial reporting, and compliance with applicable laws and regulations. Based on the above description can be concluded that the effectiveness of internal control is important in the implementation of an activity to achieve the purpose of the agency. The ineffectiveness of internal controls may open opportunities or opportunities for employees to engage in fraudulent acts because employees will exploit the ineffectiveness of internal controls as a weak point of the agency and launch its action in fraud.

H3: Internal control system negatively affects fraud trends in the public sector.

According to COSO (2004) the ethical environment of an organization includes aspects of the top management style in achieving organizational goals, their values, and management or leadership styles, it is argued that in a more ethical environment, employees will tend to follow company rules and regulations -the rules will become morally acceptable behavior so it can be said that in an ethical environment formed by a good leadership style, will affect the tendency of cheating by employees. So as to establish an ethical environment away from fraud, it takes a figure of a good leader figure in the eyes of an employee, an employee who has a bad perspire on his leader's leadership style, then the employee will tend to do things that will hurt the company, in this case, do fraud, it can be concluded that the better leadership style of a corporate leader will reduce the level of fraud committed by employees.

H4: Leadership style negatively affects fraud trends in the public sector

The organizational culture is essentially a system of general values. The personal values began to be developed early in life, as well as beliefs in general, arranged in a hierarchical system with explanatory and measurable traits, and observable behavioral consequences. Maintaining an ethical culture involving honest people; adhere to policies and codes of conduct; maintain clear and effective policies to deal with fraud and ensure that top management does so.

Organizational ethics is a pattern of attitudes and behaviors expected of each individual and group of organization members who as a whole will form an organizational culture (an organization that is in line with the goals and philosophy of the organization concerned. In the opinion of Rae and Subramaniam (2008) that in a more ethical environment, employees will tend to follow corporate rules and regulations because their behavior will be morally acceptable.

Organizational culture is the archetype accepted by organizations to act and solve problems, forming employees who are able to adapt to the environment and unify organizational members. While Robbins (2006) defines the organizational culture as a shared perception embraced by members of the organization that distinguishes organizations with one another. This is one of the characteristics of organizational value. Perceptions of organizational culture are based on the conditions experienced by a person in his organization, such as the rewards, endorsements, and behaviors expected to be gained in the organization.

Leaders can not want a high ethical and behavioral attitude of an organization while the boss himself is not serious about making it happen. Management should also show employees about the compatibility between words and deeds and not tolerate actions that violate the rules of organizational ethics that are given a clear punishment penalty and vice versa for employees who are achievers and moral well be given a proportional reward. 
The consistent execution of penalties and rewards (rewards) adds value to the creation of a strong ethical behavior and organizational structure. The employee will feel fairly treated and feel grateful for the position he has graduated if the organization's ethics can be consistently upheld by management. According to CIMA in Wilopo (2088) argues that corporate culture with low ethical standards will have a high risk of accounting fraud. The result of Wilopo (2006) study stated that unethical behavior gives a significant and positive influence on the tendency of fraud (fraud) in the company.

Based on the description above can be seen that the ethical culture of management is a picture of the behavior of management that can be emulated and imitated by the employees. Even if it is an act of fraud, the employee will justify his actions because he feels that his actions are already with the actions taken by management. Therefore, good ethical culture of management greatly affects the employee's performance and can decrease the act of fraud.

H5: The ethical culture of the organization negatively affects the tendency of fraud (fraud) in the government sector Method and Design

\section{Research Methodology}

This study uses a sample of employees working in the public sector. The public sector is the economic sector that provides various government services to the public. The population in this study is all employees working in the public sector in Makassar, such as government agencies, hospitals, state enterprises, universities, and others. Determination of the sample using a convenience the sampling technique. The sample in this research is 83 employees working in the public sector.

Data collection was done by distributing questionnaires to several public sector institutions in Makassar. The questionnaires were distributed to several hospitals, official offices, universities, SOE offices. How to collect data by using Google form media electronically. To ensure that the questionnaires were distributed to public sector employees, the investigators restricted the number of questionnaires distributed i.e. 15 questionnaires in each office with the help of employees of each office who assisted in the dissemination. This study does not specialize in one type of office due to the limited number of employees who can be met to be respondents because of the busyness of the employees. The questionnaire in this study used a Likert scale of 1-5 to measure employee perceptions by providing answer choices.

Fraud's tendency in the public sector in this research is the perception of employees regarding accounting fraud occurring in the public sector. Fraud can be interpreted as deliberate fraud, including lying, stealing, fabricating, and embezzling. Fraud itself is, in general, an unlawful act perpetrated by persons from within and/or outside the organization, with the intent of obtaining personal gain or group which directly harms the other. The measurement of fraud trends uses six question items with three indicators: financial reporting fraud, asset abuse, and corruption.

Distributive justice is the justice felt by individuals-individuals on the basis of rewards received (Stephen P. Robbins, 2008). There are 7 question items used to measure 4 Indicators. The indicators used to measure distributive justice variables such as those developed by Colqiutt (2001) are:

- Equality/equality: perception of equality or equality of business in employment in return received.

- Eligibility: perceptions about the feasibility of rewards with the completion of work.

- Contribution: perception of reward conformity with the contribution to the company.

- Performance: perception of the fit between performance and reward.

Procedural justice is the perceived fairness of an individual toward the process of determining the distribution of rewards (Stephen P. Robbins, 2008). Procedural justice indicators according to Colqiutt (2001) are process control, decision control, consistency, prejudice, the accuracy of Information.

The internal control system uses five indicators based on COSO's internal control system elements (2004) and PP number 60 of 2008 on SPI namely control environment, risk assessment, control 
activities, information and communication, monitoring and internal control. Leadership style is measured by using indicators developed by Fiedler in Robbins (2010), leadership and subordinate relationships, task structure, strength positions, achievement orientation, participative leadership. The ethical culture of the organization is measured using the indicators developed by Moeljono (2003), namely penalties for unethical action, ethical protection mechanisms, visible role model, ethical expectations communication, ethics training.

\section{Result and Discussion}

Construct Validity Test. The construct validity test is measured by the loading scores parameter on the research model (Rule of Thumbs $>0.7$ ) using the loading scores parameter and the AVE score should be $>0.5$. In this research, the results show the score of loading construct shown in the following figure.

Figure 1. First Stage Test Results

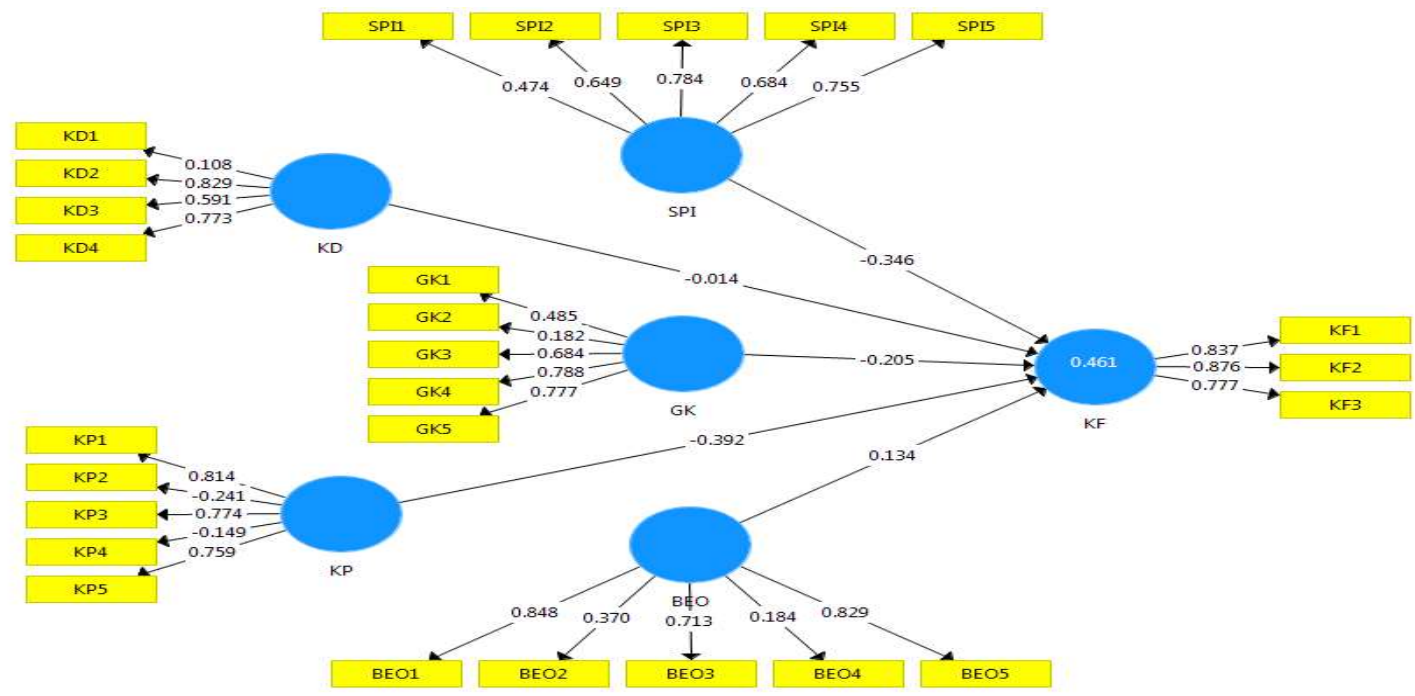

The following figure shows that in the KD (distributive equity) construct, the Rule of Thumbs $>0.7$ scores only the KD2 and KD4 indicators because the loading scores are above 0.7 . Other constructs that have values below 0.7 will be removed from the model, resulting in the following model.

Figure 2. Model of the second test phase

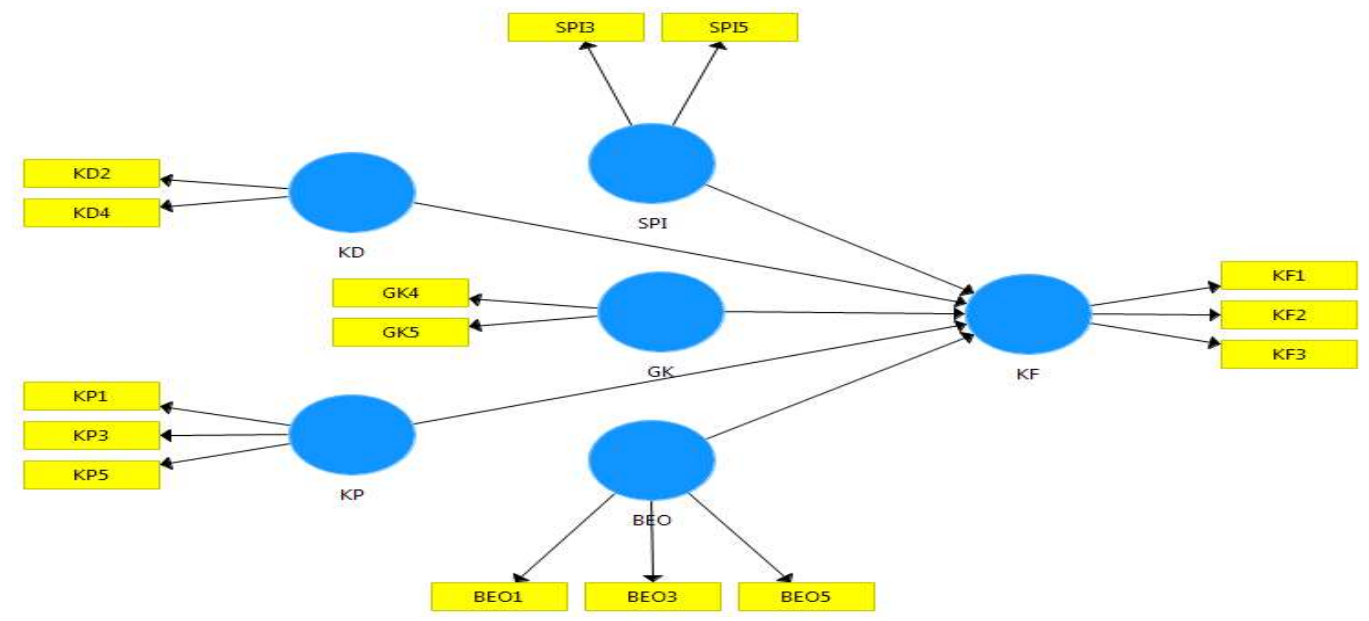


After eliminating the indicators that are not loaded into the constructs it represents. Then tested the validity of the construct with the test of Convergent Validity and Discriminant Validity.

Convergent validity test parameters are viewed from the AVE score on the condition that each variable should be above 0.5. Based on table 4 below, all constructs have an AVE value above 0.5. This means that the probability of an indicator in a construct for entry to another variable is lower (less than 0.5 ) so that the probability of the indicator converges and enters into a larger targeted construct that is above 50 percent.

Table 4. Output of Outer Model Test

\begin{tabular}{|l|c|c|c|c|}
\hline & $\begin{array}{c}\text { Cronbach's } \\
\text { Alpha }\end{array}$ & rho_A & $\begin{array}{c}\text { Composite } \\
\text { Average } \\
\text { Variance }\end{array}$ & $\begin{array}{c}\text { Reliability } \\
\text { Extracted } \\
\text { (AVE) }\end{array}$ \\
\hline Ethical Culture Organization & 0,759 & 0,768 & 0,862 & 0,677 \\
\hline Leadership Style & 0,671 & 0,691 & 0,823 & 0,670 \\
\hline Distributive Justice & 0,761 & 0,789 & 0,817 & 0,692 \\
\hline Fraud Tendency & 0,776 & 0,792 & 0,870 & 0,690 \\
\hline Procedural Justice & 0,711 & 0,712 & 0,838 & 0,633 \\
\hline Internal Control & 0,694 & 0,799 & 0,854 & 0,745 \\
\hline
\end{tabular}

Based on Table 4 we can see the discriminant validity result that shows the AVE square root value of each construct is greater than the correlation value between the construct and the other constructs in the model, it is said to have a good discriminant validity value.

Table 4 shows that the results of Cronbach alpha and composite reliability show the satisfactory value that is the value of each variable above the minimum value of Cronbach alpha 0.6 and the minimum composite reliability value 0.7 . It shows the consistency and stability of the instrument used are high. Inner model or structural model testing is done to see the relationship between construct, significance value and R-square of the research model.

Table 5. R-Square

\begin{tabular}{|l|c|c|}
\hline & R Square & R Square Adjusted \\
\hline Fraud Tendency & 0,487 & 0,452 \\
\hline
\end{tabular}

Table 5 shows that the value of R-square. The fraud trend in the public sector in Makassar is 0.487 . R-square value of 0.487 means that variability of fraud tendency in public sector in Makassar city can be explained by construction variability of KD, KP, SPI, GK, and BEO, by $48 \%$ while $52 \%$ is explained by other variables outside of the study.

The results of hypothesis testing can be seen in the test output of Path coefficient in the following table.

Table 6. Path coefficient

\begin{tabular}{|c|c|c|c|c|c|}
\hline Original & Sample (O) & $\begin{array}{c}\text { Sample } \\
\text { Mean (M) }\end{array}$ & $\begin{array}{c}\text { Standard } \\
\text { Deviation }\end{array}$ & $\begin{array}{c}\text { T Statistics } \\
\text { (O/STDEV) }\end{array}$ & P Values \\
\hline KD -> KF & $-0,083$ & $-0,087$ & 0,101 & 0,819 & 0,413 \\
\hline KP -> KF & $-0,264$ & $-0,244$ & 0,125 & 2,114 & 0,035 \\
\hline SPI -> KF & $-0,374$ & $-0,372$ & 0,099 & 3,779 & 0,000 \\
\hline GK -> KF & $-0,229$ & $-0,239$ & 0,111 & 2,070 & 0,039 \\
\hline BEO -> KF & $-0,021$ & $-0,001$ & 0,117 & 0,184 & 0,854 \\
\hline
\end{tabular}


Based on the path coefficient test in Table 6, the test results show that KD (distributive justice) and BEO (organizational ethical culture) have no effect on fraud trends. T-statistics show a value below 1.659 and P-value which shows a significant value above 0.05. KD hypothesis which states that distributive justice has an effect on fraud tendency is rejected because t-statistic value equal to 0,819 $<1,659$ and value of $\mathrm{P}$-value $>0,05$ is 0,423 . This result contradicts the research results of Adinda and Ikhsan's research (2015).

The second hypothesis that procedural justice negatively affects the fraud tendency is accepted. The $\mathrm{t}$-statistic value of 2.114 is greater than the value of $\mathrm{t}$-table 1.96 and the $\mathrm{p}$-value value is $0.035<0.05$ and the coefficient is -0.264 . Statistics show that procedural justice negatively affects fraud trends. The results of this study are in accordance with a research by Adinda and Ikhsan (2015). This study supports the opinion of Greenberg and Baron (2003) which states that procedural justice is a perception of justice for decision making within the organization. People in the organization are very concerned in making decisions fairly that prevents people from committing fraud.

This result is also in accordance with an opinion (Palupi, 2013) that justice does not simply compare inputs and outputs, but employees identify how processes and procedures in determining an outcome prevent them from committing fraud. Based on the analysis of the test equipment, influential indicators and the size of the construct is the control of the process, consistency, and accuracy of information. This measure was developed by Colqiutt (2001).

Internal control system negatively affects fraud trends. The results show the third hypothesis is accepted. The higher the perception of the effectiveness of SPI then reduces the tendency of cheating. The significance value of $0.000<0.05$ and t-statistics 3,779 and the coefficient -0.374 which showed a negative effect on the tendency of cheating. These results support Pramudita's research (2013), Wilopo (2006), Adinda and Ikhsan (2015), Faisal (2013), Puspasari and Suwardi (2012). The indicators that constitute the size of the construct are the activities of control and monitoring as well as the internal control. This indicator is developed from COSO's internal control system elements (2004).

There is a negative influence of leadership style on the fraud tendency of employees working in the public sector. The t-statistic and p-value values show the values of 2.070 and 0.039 . The coefficient of -0.299 shows the direction of the negative relationship. The higher the perception of leadership style then the tendency of fraud is decreasing. These results are consistent with Aditya's (2013), and COSO (2004) research results that the ethical environment of an organization includes leadership styles in achieving organizational goals, their values and management style, creating a more ethical environment, and employees will tend to follow company regulations so as to reduce fraud. The indicators used in measuring leadership style constructs were developed by Fiedler in Robbins (2010). Based on statistical testing tools, constructing indicators are leaders that are achievement-oriented and have participative leadership styles.

\section{Conclusion}

The result of the research shows that there is a negative influence of procedural justice variable, internal control system and leadership style to fraud on employee working in the public sector in Makassar city. Perceptions of procedural justice cause the people within the organization to feel fair in terms of the company's treatment of each individual. The existence of a sense of justice is what makes the reduction of the tendency of cheating. A good internal control system will prevent the employee's tendency to cheat because a good control system will make the individual think to cheat. Leadership style will prevent fraud because employee perceptions of leaders who have a typical leadership style will reduce employees to cheat. Leaders who are participative and open and engage broad-based and achievement-oriented employees will prevent individuals from cheating.

This research contributes to the development of research on fraud topics. Indonesia's number one problem is corruption. Corruption is most prevalent in the public sector. Various actions taken by the government do not seem to succeed in reducing the act of fraud (fraud) which one of them is 
corruption. For further research, there are many variables that may affect the tendency of individuals to commit fraud. It may also have to do with political connections, as we know that the average in Indonesia who is corrupt is a person who has a political network.

\section{References}

Association of Certified Fraud Examiners (ACFE) (2008). Association of Certified Fraud Examiners. 2008. Report to The Nation on Occupational Fraud and Abuse. ACFE.

Betts, D. 2009. The Psychology of Fraud: What Makes Employee Cross The Line? Joint ACFE.ISACA.

COSO. 2004. Enterprise risk management - integrated framework. Committee of Sponsoring Organizations

Cressey Donald R.1953. Other people money, A study in the social psychology of Embezzlement. Montclair: Patterson Smith.

Faisal, Muhammad.2013. "Faktor- Faktor Yang Mempengaruhi Terjadinya Fraud Di Sektor Pemerintahan (Persepsi Pegawai Pada Dinas Se-Kabupaten Kudus)". UNNES.

Gbegi \& Adebisi. 2013. The New Fraud Diamond Model- How Can It Help Forensic Accountants In Fraud Investigation In Nigeria?. European Journal of Accounting Auditing and Fiancé Research Vol.1, No. 4, pp.129-138. UK.

Greenberg, J. And Robert A. Baron. 2003. Behavior in Organization International Edition, New Jersey: Prentice Hall.

Ikhsan,Arfan \& Muhammad Ishak .2005. “Akuntansi Keperilakuan”.Jakarta: Salemba Empat.

Ivancevich dkk, 2006, Perilaku dan Manajemen Organisasi, Jilid Satu, Erlangga, Jakarta.

Kartini. 2008, Pemimpin dan kepemimpinan. Jakarta.

Mustika,Dhermawati P.2013.'Persepsi Pegawai Dinas Se-Kabupaten Batang Tentang Faktor- Faktor Yang Mempengaruhi Kecurangan (Fraud)".Skripsi.SI FE UNNES.

Palupi, Sri. 2012. Persoalan Psikologis Wanita Menopause.

Rae and Subramaniam.2008. "Quality Of Internal Control Procedures Antecedents And Moderating Effect On Organisational Justice And Employee Fraud.” Managerial Auditing Journal Vol. 23 No. 2, 2008 pp. 104-124.

Rawls, John. 2006. Teori Keadilan Dasar-Dasar Filsafat Politik Untuk Mewujudkan Kesejahteraan Sosial dalam Negara, Terjemahan Uzair Fauzan dan Heru Prasetyo. Yogyakarta: Pustaka Pelajar.

Robbins, Stephen P. 2003. Perilaku Organisasi. Index. Jakarta.

Robbins, S. 2006. Perilaku Organisasi. Jilid II. Jakarta: Salemba Empat.

Thibaut, J. dan Walker, L. (1978). A theory of procedure California Law Review, 66(3), 541-566.

Tuanakotta, Theodorus.2007."Akuntansi Forensik \& Audit Investigatif” Jakarta : Lembaga Penerbit Fakultas Ekonomi Universitas Indonesia.

Tyler, T.R. \& Blader, S.L. (2003). The group engagement model: procedural justice, social identity, and cooperative behavior. Personality and Social Psychology Review, 7(4):349 361.

Tunggal, Amin Widjaja. 1992. Pemeriksaan Kecurangan (Fraud Auditing), Rineka cipta: Jakarta Amin Widjaja Tunggal. 2009. Kecurangan Laporan Keuangan (Financial Statement Fraud). Jakarta : Harvarindo.

UU No. 60 tahun 2008 tentang SPIP

Puspasari, Novita \& Suwardi, Eko.2012.’Pengaruh Moralitas Individu dan Pengendalian Internal terhadap Kecenderungan Kecurangan Akuntansi: Studi Eksperimen pada Konteks Pemerintah Daerah".Jurnal.Yogyakarta : FEB UGM.

Wilopo. 2006. "Analisis Faktor-Faktor yang Berpengaruh terhadap Kecenderungan Kecurangan Akuntansi : Studi pada Perusahaan Publik dan BUMD di Indonesia". Simposium Nasional Akuntansi 9 Padang.

Ziengenfuss, 1999. Differences in personal ethical philosophy among accounting students and 
between accounting students and practitioners. Douglas E. Southern Business Review; Statesboro, Ga. Vol. 25 